ЗДРАВСТВЕНА ПСИХОЛОГИЈА У АКАДЕМСКОМ ОБРАЗОВАЫУ

Весна В. Томић ${ }^{1}$

\title{
HEALTH PSYCHOLOGY IN THE ACADEMICAL EDUCATION OF HEALTH WORKERS
}

Vesna V. Tomić

\section{Сажетак}

Циљ рада је да елаборира неке од могућности практичне примене здравствене психологије ибихевиоралнемедицине y медицинској пракси, све у контексту медииинске континуиране едукације.

У препорукама предлажемо:

1. Континуирану интердисииплинарну едукацију здравствених професионалача.

2. Коришћење постојећих професионалних ресурса у том домену.

3. Развијане унутрашье мотивачије здравствених радника за самообразовање.

4. Инкорпорирање психолошких знања и вештина у редовну наставу за све здравствене раднике.

5. Стварање услова за увођене здравствене психологије у наставу.

Закључак: неопхоно је одређена знана из сочијалних вештина инкорпорирати у медиџнско образовање здравствених радника свих профила.

Кључне речи: здравствена психологија, бихевиорална медицина, образовање, едукайија.

\section{Summary}

The aim of this paper is to analyze some aspects of applications of health psychology and behavioral medicine in medical practice, all in context of continual medical education.

The paper suggests:

1. Continual interdisciplinary education of health professionals.

2. Using of professional resources in that domain.

3. Developing a inside motivation of health workers for selfeducation.

4. Including the psychological knowledge and skills in regular education.

5. Making conditions for include health psychology in education.

Conclusion: it is necessary to include knowledge and skills from health psychology in regular education of health workers.

Key words: health psychology, behavioral medicine, education.

Нема ништа страшније од незнаға у акцији. (Гете)

\footnotetext{
${ }^{1}$ Др сц. мед. Весна В. Томић, социјални психолог, Институт за јавно здравље Србије „Др Милан Јовановић Батут“, Београд.
} 


\section{ПРОБЛЕМ}

$\mathrm{Y}$

нашој образовној пракси не прави се разлика између професионалног усавршавања - едукације здравствених радника и њиховог образовања и самообразовања. Иако обе образовне активности имају за циљ побољшање квалитета радне ефикасности здравствених радника и тиме побољшање квалитета здравствене заштите, између њих постоје значајне разлике које се односе на:

- Обим садржаја који третирају тако што је образовање знатно обимније од различитих форми едукација (семинара, предавања);

• Облике учења-тако што је жељени ниво наученог у образовању репродукција знања, а у едукацији је рекогниција (препознавање). Сложенији облик учења је репродукција;

- Начине реализације - образовање и самообразовање трају кроз цео професионални век, а едукације су ad hoc, према потреби;

- У образовању је ангажована унутрашња мотивација (мотиви постигнућа и самоактуализације), а у едукацији спољашња мотивација (сакупљање поена за оверу лиценци).

\section{УВОД}

Овај рад биће фокусиран на тему вођења наставне јединице здравствене психологије за све нивое образовања здравствених радника и профиле свих здравствених струка. Кроз различите видове континуиране медицинске едукације презентују се садржаји из домена здравствене психологије и бихевиоралне медицине у трајању од неколико сати (обично 6), а реализују их различити профили здравствених радника који за то нису компетентни, а на основу формално испуњених пропозиција за акредитацију од стране Комисије за акредитацију која строго води рачуна о форми едукације. Садржају и реализацији едукације пажња се посвећује минимално, тек онолико колико то мора по закону о континуираној медицинској едукацији.

Историјски гледано, медицина и психологија као научне области нису имале превише заједничког. Настале су из различитих извора, са другачијим циљевима и у различито време. Медицина, из искустава о телесном функционисању током болести и здравља, у доба раних цивилизација наше ере. Психологија, из филозофије од које се одваја крајем XIX и почетком XX века усвојивши принципе научног развоја, али и осталих облика човековог функционисања. Здравље је за медицину дуго било само телесно, а за психологију само ментално. Сазнања да у здрављу и болести партиципирају обе ове компоненте, приближило је ове две области. Психолози су се активније укључили у процесе дијагнозе, третмана и превенције медицинских проблема. Понудили су своју методологију истраживања у области здравља и болести, етиологије и ризико фактора за настанак различитх обољења, као и елемената који доприносе успешном лечењу. Понудили су и своју клиничку праксу. Посебно значајан удео дала је социјална психологија у превенцији и спречавању настанка многих незаразних обољења, као и откривању фактора зашто се људи на различуте начине односе према здрављу и болести. Створили су се услови за развој здравствене психологије, нове области настале у циљу објашњавања удела психолошких фактора у унапређивању здравља, настанку болести и реакцијама на болест. У делу који је референтан за здравствени менаџемент, део који третира људске ресурсе, као и механизме одвијања и функционисања здравствених установа и посебно садржаје интеракције лекар пацијент, све психолошке варијабле од структуре и динамике функционисања групе, преко социјалне и емоционалне интелигенције, емпатије и поверења, до 
решавања конфликата, мотивисања запослених и управљања стресом и мобингом драгоцени су садржаји кроз које психологија налази своје место у медицинској теорији и пракси.

\section{Појава бихевиоралне медицине}

Некада су се здравље и болест посматрали као дихотомне категорије које се узајамно искључују. Здравље, као унапред дато, болест као недостатак који га ремети и прекида. Последњих неколико деценија схватања се мењају. Здравље и болест се посматрају као крајеви континуума дуж кога постоје застоји, динамика односа између променљивог организма и бројних патогених агенаса, развој и адаптација организма на срединске факторе.

Поставка да је настанак болести условљен сталном интеракцијом организма и средине довела је до схватања да положај особе дуж тог континуума зависи и од спољашњих и од унутрашњих фактора. О здрављу се све више говори да је оно у кореалцији са понашањем особе, животним стилом, психолошким и социјалним факторима - факторима на које се може деловати директно и вољно за шта је потребна професионална основа.

Као реакције на оваква и слична схватања дошло је до стварања појма бихевиоралне медицине, почетком осамдесетих година прошлог века. Појам означава широк мултидисциплинаран приступ научног истраживања, образовања и праксе који се тичу болести и здравља. У суштини је представљао интеграцију бихевиоралних наука, међу њима посебно психологије са медицинском науком и праксом.

\section{Настанак здравствене психологије}

Здравствена психологија као посебна грана психологије почиње да се развија у свету крајем седамдесетих година XX века. На њен настанак утицали су: обнављање интереса за холистички приступ човеку и утицај психолошких фактора у настанку многих обољења.
Најшире прихваћену дефиницију здравствене психологије дао је Matarazzo, ${ }^{(2)}$ наводећи да она представља: „Агрегацију одређених едукативних, научних и стручних доприноса психологије, пољима унапређења и одржавања здравља, болести и дисфункција које су са њима у вези, као и побољшања система здравствене заштите“. Овом дефиницијом прави се суштинска разлика између здравствене психологије и бихевиоралне медицине. Дефиниција подразумева деловање психологије на веома широку проблематику. Неки здравствени психолози виде себе као клиничаре, други као социјалне психологе, трећи као когнитивне психологе, четврти као психофизиологе.

Клиничка психологија, као посебна грана психологије, бави се људима са психолошким проблемима, поремећајима или ментално оболелима и историјски гледано представља први улазак психологије у области здравља и болести. Здравствена психологија је грана психологије која се бави здрављем и болешћу у најширем смислу и концептуално је шира област од клиничке психологије коју укључује, али и превазилази. У медицину је ушла преко различитих грана соматске медицине и превентивне здравствене заштите.

Здравствена психологија креирала је био-психо-социјални модел здравља и болести које их третирају као последицу интеракције биолошких, психолошких и социјалних фактора. Било да се ради о здрављу или болести дух и тело су нераздвојни. У основи овог приступа је да су сви нивои организације ентитети међусобно хијерархијски повезани и да промена на било ком нивоу утиче се на промене у свим осталим.

На нивоу успостављања дијагнозе и при избору одговарајуће терапије увек треба имати у виду садејство наведених фактора, због чега се препоручују интердисциплинарни тимови. У разматрању ефикасности лечења, брзине опоравка и пра- 
вовременог тражења лекарске помоћи био-психо-социјални модел истиче значај адекватног односа лекар-пацијент. Од лекара се очекује да разуме социјалне и психолошке факторе који доприносе болести, како би био у стању да омогући што боље лечење и допринесе бржем опоравку пацијента. Од психолога у клиничкој пракси очекује се да у домену својих компетенција помогне болеснику и његовој породици кроз индивидуални рад са њим.

\section{ЕДУКАЦИЈА ЗДРАВСТВЕНИХ РАДНИКА}

Едукација здравствених радника свих профила, онако како се реализује у последњих 7-8 година, преко акредитованих семинара узлимитирање једног предавачана 2 сата, не пружа готово никакве могућности за развијање бихевиоралне медицине и здравствене психологије у њој, без обзира на потенцијални мотивацију слушалаца и њихове практичне професионалне потребе.

На овај начин знања која се нуде једва да се могу задржати на нивоу рекогниције (препознавања садржаја), док је остваривање степена усвојених знања кроз ретенцију (задржавање) и репродукцију (могућност понављања наученог) готово немогућа. Чак ни висок степен унутрашње професионалне мотивације и самообразовање и континуирано учење нису довољни, због недостатка елементарних психолошких знања која су у основи здравствене психологије.

Начин одвијања континуиране медицинске едукације са аспекта мотивације слушалаца развија искључиво спољашњу мотивацију, засновану на квантификацији: броја поена који носи, цени коштања едукације, месту њене реализације, трајању. Тиме су садржаји који су корисни или неопходни, као и предавачи који их реализују, скоро сасвим маргинализовани.

Напред наведено се односи на садржаје бихевиоралних наука немедицинске при- роде, не на оне садржаје кроз које се обраћају здравствени радници једни другима са садржајима из својих професионалних области!

Када се ради о руководиоцима здравствених установа, из резултата истраживања се зна да је за менаџере најлакше прихватити неку техничку вештину, далеко теже хуману вештину, а врло тешко концептуалну вештину. Katz и група истраживача сложили су се у следећем:

- Најлакше је за менаџера да прихвати техничку вештину кроз различите форме усвршавања, додипломским и последипломским.

- Много је теже овладати хуманим вештинама у које спадају и социјалне вештине. Разлог за то је што оне укључују сложене емоционалне компоненте и базична психолошка знања. Позната је и чињеница да је лакше људима да кажу да су необучени у неком техничком знању, него да науче нове бихевиоралне шеме у односима са другим људима или промене своје дотадашње шеме и моделе понашања. Данас се у свету праве озбиљни покушаји да се у образовању здравствених радника побољшају методе у раду са људима: колегама и пацијентима.

- Учење концептуалних вештина је тешко, јер оне укључују менталне навике које се развијају целог живота.

Знања из домена здравствене психологије и бихевиоралне медицине неопходна су за руководиоце здравствених установа. Постојали су покушајиу периоду 1997-2000. године када је у Институту за јавно здравље организоавана специјализација за све директоре здравствених установа из Србије. Курс (специјализација) је подразумевао годину дана наставе из домена социјалне медицине и бихевиоралне медицине, али је нагло прекинут услед развоја одређених друштвених околности, а слушаоцима је преостало да ураде специјалистичке радове из области њихове делатности, које 
су они касније реализовали на различитим нематичним факултетима.

Образовањем здравствених радника из домена здравствене психологије остварио би се:

1. Систематски развој одговарајућих знања (на нивоу репродукције) из области социјалних вештина у медицинској пракси.

2. Развој практичних вештина из именоване области.

3. Формирали би се ставови који би професионалцу помогли да реализује практичне циљеве здравствене установе и заједнице.

Поред наведеног образовног циља, знањима и вештинама из здравствене психологије здравствени радници би били оспособољени да:

- комуницирају са колегама, пацијентима и грађанством

- сарађују и тимски раде са сарадницима,

- континуирано едукују из друштвених наука,

- мотивишу себе и своје колеге развијањем интеристичке мотивације,

- решавају и спречавају конфликтне ситуације,

- управљају стресом и мобингом,

- креирају конструктивне ставове у односу на промене, научне и друштвене,

- развијају социјалну и емоционалну интелигенцију,

- развијају поверење и емпатију у односу са корисницима здравствених услига,

- ефикасно комуницирају са представницима мас-медија,

- развију персоналне диспозиције значајне за медицинску праксу.

Вероватно да ниједна књига сама по себи не може да научи појединца како да постане добар здравствени радник. Учење не захтева само знање и персоналне диспозиције, него и праксу у употреби различитих медицинских вештина.
Главна функција овога рада је да прикаже релевантну информацију на систематски начин. Посебно осетљива је ситуација када се одређени садржаји који су ван директне медицинске струке (из домена техничких вештина), а у директној су вези са медицинском праксом и раду са људима (из домена хуманих вештина), може да изазове бројне отпоре у медицинском еснафу. Коришћење оваквих текстова не значи аутоматски спремност за преузимање свих одговорности здравствених радника, али ће омогућити упознавање са многим начинима како да се побољша квалитет здравствених услуга и здравствене заштите.

\section{Дилеме и потенцијални проблеми у вези са образовањем здравствених радника из здравствене психологије}

Коме је намењено ово образовање?

- лекарима,

- стоматолозима,

- фармацеутима,

- медицинским сестрама,

- осталом здравственом кадру запосленом у здравственим установама,

- руководиоцима здравствених установа,

- студентима факултета здравствених струка.

Које области обухвата образовање из здравствене психологије?

- социјалну психологију,

- медицинску психологију,

- психологију менаџмента,

- психологију међуљудских односа,

- психологију рада,

• психологију личности.

Коме је потребно ово образовање?

- здравственим радницима запосленим у здравственим установама,

- свим корисницима здравствених услуга.

Како искористити претходна знања и вештине? 
- уградити их у већ постојећа знања,

- проценити колико та знања могу стварно да допринесу у пракси,

- образовати се даље у том правцу.

Када почети са едукацијом?

Већина тема из здравствене психологије презентирана је кроз једнодневна предавања континуиране едукације, која су одржана на Медицинском факултету у Београду, у Институту за јавно здравље Србије, Фармацеутској Комори, удружењима сестара и техничара, Стоматолошком факултету, и то пре формирања комисије за акредитацију, али проблем је у томе што њих треба уградити у студије и специјализације у надлежним институцијама (факултетима). Наведени семинари били су реализовани након одобрења од стране Јединице за континуирану медицинску едукацију Медицнског факултета у Београду.

У сваком случају, са едукацијом треба почети што раније и детаљније кроз предавања и тренинг модуле за слушаоце.

Ко треба да спроводи образовање?

Образовање треба да реализује психолог са највишим научним звањима и праксом у систему здравствене заштите како би могао да задовољи когнитивне и практичне потребе здравствених радника. Добро би било да у тиму са психологом буде и искусан лекар специјалиста социјалне медицине.

\section{Предуслови успешног образовања из здравствене психологије}

Да би образовање здравствених радника из области бихевиоралне медицине и здравствене психологије било успешно у пракси, потребно је да буду задовољени следећи предуслови:

1. Развијен здравствени систем који је у стању да препозна неведене здравствене потребе, законска регулатива, отворена комуникација, известан број кадрова обучених за рад у овој области, политичка подршка.
2. Одговарајућа претходна едукација - претходно школовање, може поред техничког знања, да обезбеди да се та врста образовних потреба препознају у систему здравствене заштите.

3. Одговарајући наставни кадар - за семинаре кроз које се реализује континуирана медицинска едукација, од почетка би требало омогућити ангажовање компетентних кадрова (психолози), а не здравствених радника свих нивоа, бар у оним семинарима који се претежно односе на област здравствене психологије. Одговарајући наставни кадар треба да мотивише људе за учење оних области које не третирају научна медицинска стручна знања.

4. План образовања - сваки образовни круг треба да садржи следеће етапе: планирање - области, часова, предмета; организовање - материјала, места и времена; мотивисање слушалаца за стицање нових знања; презентирање - предмета и области, евалуирање - успешности наставе према постављеним циљевима и нивоима знања.

5. Одговарајући наставни методи - у реализацији наставних јединица треба комбиновати методе предавања и тренинг модула (практичне обуке). Ако се пође од циљева наставе:

- схватање, интерпретација наученог материјала,

- примена појмова и принципа,

- памћење основних појмова (на нивоу репродукције, не ретенције и рекогниције),

јасно је да захтеве није лако остварити у пракси уколико се немају јасно зацртани циљеви и резултати који се желе постићи.

6. Одговарајући услови за реализацију наставе - подразумевају одговарајуће просторије и опрему.

7. Мотивисани кадрови и учесници едукативног процеса - оба у циљу промена у оквиру здравственог система у 
будућности са циљем хуманизовања медицинске теорије и праксе, као и бољих исхода здравствене заштите.

8. Могућност даљег усавршавања у току рада и прихватање образованих кадрова од стране здравственог система.

9. Квалитетни уџбеници и приручници у многоме ће својом јасноћом и прилагођеношћу да употпуне знања и омогуће њихов трансфер на медицинску праксу.

Очигледно је да ће задовољење свих предуслова за успешно образовање бити тешко оствариво у нашој средини, зато је потребно што је могуће више стварати предуслове за остваривање таквог наставног програма.

У склопу описаног нивоа образовања могуће је интегрисати и садржаје здравственог менаџемента који третирају интерперсоналне вештине као један од сегмената образовања здравствених радника и њихово оспособљавање за руковођење здравственом установом.

\section{Перспективе развоја здравствене психологије у области континуиране медицинске едукације}

Из досадашњег садржаја овог поглавља јасно је да развој социјалних вештина кроз садржаје здравствене психологије и бихевиоралне медицине није чаробан штапић којим ће се унапредити функционисање система здравствене заштите, али је значајан предуслов да се све оно што прати немедицинске садржаје функционисања здравствених установа може да учини ефикаснијим и сврсисходнијим са аспекта корисника здравствене заштите.

Са аспекта континуиране медицинске едукације перспективе развоја и примене социјалних вештина у медицинској пракси су минималне, или статистичким језиком речено занемарљиве. Добар корак у првацу подстицања развоја ове области био би да се омогуће целодневне и/или вишедневне едукације (6 сати у трајању од 2 до 3 дана) у реализацији професионално школованих кадрова за ту област, а уз сарадњу и укључивање лекара (посебно специјализације из социјалне медицине) и медицинских сестара у реализацију едукација.

Када се обрати пажња на практичну обуку у оквиру реализованих семинара, намећу се следеће чињенице као закључци:

1. Не води се рачуна о броју слушалаца (учесника) семинара тако да њихов број варира од 50 до 250. То су услови у којима тешко може да се реализује и ваљано предавање, а његова практична примена је скоро немогућа, уколико је циљ да се нешто научи.

2. Што се тиче садржаја практичних вежби, тренинг модули се не планирају унапред, већ се под неодговарајућим термином радионица (преузетог из предшколске педагогије) ради како коме падне на памет.

3. Примена квази тестова знања, такође, нема смисла, јер је немогуће остварити било какву и толику квантификацију знања након неколико часова едукације. Зна се из андрагогије, да би се стекла одређена знања на нивоу репродукције, треба од 6 до 12 целодневних едукација.

4. Завршни упитник о евалуацији едукација нуди у највећој мери социјално пожељне одговоре иако је анониман.

5. Садржаје немедицнских едукација реализују по одређеном шаблону сви, од лекара до медицинских сестара иако за то немају потребна знања, а камоли да могу да их ситематски повежу и елаборирају.

Учинак кроз тако остварене едукације је минималан тако да је неопходно нешто озбиљно мењати у систему континуиране медицинске едукације или ће у противном све остати на броју прикупљених поена у току године ради оверавања лиценце.

Искусан едукатор из области здравствене психологије пажљиво:

- планира наставу - обуку, 
- извршава план према основним дидактичким принципима андрагогије,

- стално има на уму циљеве образовања: промене у знању и понашању,

- организује наставу, материјал, средства, време, програм,

- мотивише људе за интерактивно учење и стицање знања на нивоу реперодукције,

- води предавање - пита, дискутује, подстиче учеснике,

- помаже при апликацији тренинг модула,

- пажљиво и стрпљиво исправља грешке,

- адекватном методологијом евалуира ефекте оствареног процеса учења и трансфера знања.

Методе рада у андрагогији (образовању одраслих) претрпеле су одређене промене. Метода предавања давно је превазиђена радом у малој групи у којој се кроз интерактивно учење и одговарајуће тренинг модуле елаборирају циљани садржаји. У свету се доста користе и online едукације, али је овај облик рада код нас у настајању. Слушаоци више само не уче него и разумевају, процењују, исказују, дискутују, припремају, анализирају, закључују - све то у функцији реализације једног од циљева наставе: трансфера са знања на праксу.

\section{КРИТИЧКИ ОСВРТ И ЗАКЉУЧНО РАЗМАТРАЫЕ}

Потпуно је невероватно да у XXI-ом веку, веку експанзије и доступности знања између различитих научних дисциплина, систем здравствене заштите у нашој средини, на нивоу надлежних институција не препознаје професионалну и практичну потребу за хуманизацијом медицинске праксе у свим нивоима здравствене заштите. Сувопарна квантификација техничких знања неће утицати на побољшање задовољства корисника здравствених услуга квалитетом пружене здравствене заштите, јер на то у великој мери утиче квалитет интеракције између лекара и пацијента. Зашто је наш систем државних и референтних институција здравственог система још увек на нивоу проучавања од стране невладиног сектора о томе како да хуманизују здравствене установе и који су приоритети у томе, остаће питање без одговара у приручнику, али ће сигурно испровоцирати на размишљање о том проблему са одређеним предубеђењем. Стање у здравственом систему је такво да тражи неопходне промене у свим сегментима организације здравствене заштите, посебно у оним деловима где људи раде за људе и са људима - а све то у интересу људи и њиховог здравља.

Овај чланак заокружићу напорима да се проникне у смисао и значај медицинске етике у којима ће свако од читалаца покушати да одговори на основна питања:

1. Шта је уопште етика, правећи дистинкцију између етике и морала?

2. У каквом су односу практично морално понашање и теоријска етика?

3. Који су услови и критеријуми етичког понашања и процењивања?

Закључке и импресије о прочитаном раду поделите са собом и својим колегама!

Питања

1. Зашто је уведена континуирана медицинска едукација у здравствени систем?

2. Зашто мислите да је уведена Комисија за акредитацију програма на годину дана, када на Медицинском факултету у Београду постоји Центар за континуирану медицинску едукацију?

3. Шта мислите о увођену здравствене психологије и бихевиоралне медицине у основно образовање здравствених радника?

4. Шта мислите о едукацијама којима сте присуствовали?

5. Да ли би вас мотивисало интердисциплинарно третирање медицинске праксе кроз наставу? 
6. Шта вас покреће за континуирану медицинску едукацију?

7. Шта бисте ви променили у досадашњем медицинском образовању здравствених радника?

8. Да ли мислите да су за здравствени менаџмент важна знања из домена управљања људским ресурсима?
9. Зашто тако мислите - образложите.

10. Зашто се математичком прогресијом повећава број здравствених радника без оверених годишњих лиценци?!

\section{ЛИТЕРАТУРА}

1. Gatchel RJ, Baum A., Krantz DS. An introdusction to Health Psychology. Mc Graw- Hill, Book Company, 1989.

2. Matarazzo JD. Behavioral health and behavioural medicine: Frontiers for a new health psychology. American Psychologist 1980; No 35: 807-817.

3. Tayler SE. Health Psychology. Mc Graw Hill, Inc (third ed.), 1999.

4. Бергер Д., Бергер Ј., Митић М., Томић В. Здравствена психологија. ДПС, ЦПП, Београд, 1997.
5. Sarafino EP. Health Psychology: biopsychosocial interactions. John Willey and sons. Inc, $3^{\text {rd }}$ ed. New York, USA, 1998.

6. Ogden I. Health Psychology. Mc Graw Hill ed., Arizona, USA, 2012.

7. Murray M. Critical health psychology, published online, 2015.

8. Wilson DK. The relevance, impact and reach of behavioral medicine. Annals od behavioral medicine, 2015; No 49: 40-48.

Контакт: Др сц мед. Весна В. Томић, социјални психолог, Институт за јавно здравље Србије “Др Милан Јовановић Батут”, Београд. 